\section{German Universities Open Doors to Refugees: Access Barriers Remain}

\section{Simon Morris-Lange ANd Florinda BrandS}

Simon Morris-Lange is deputy head of the research unit Expert Council of German Foundations on Integration and Migration, Berlin, Germany. E-mail: morris-lange@svr-migration.de. Florinda Brands is a migration policy expert, Berlin, Germany. E-mail: florinda.brands@gmail. com. The arguments and conclusions contained here do not necessarily reflect the opinion of the Expert Council of German Foundations on Integration and Migration.

Furope, and Germany in particular, have seen a great inEflux of asylum seekers over the past months. In 2015 alone, the number of men, women and children seeking asylum in Germany is projected to reach a historic high of close to I,०००,०००, which has proved to be a major challenge for the country's established processing channels. However, with great challenges come great opportunities: The majority of asylum seekers are under the age of 25 and well suited to help offset the decline of Germany's aging population. Many of the newcomers have attended or had planned to attend university before they had to flee their home country. This desire to learn has not gone unnoticed, as many German universities and other higher education institutions are opening their doors to asylum seekers. However, for many of them, taking up or continuing their studies remains a distant dream, as legal and financial barriers pose a seemingly insurmountable challenge. For Germany, a failure to address these barriers today could result in a lack of successful integration tomorrow, since around 35 percent of asylum seekers are expected to stay long term.

\section{LEGAL BARRIERS}

Although the questions surrounding asylum procedures and integration measures continue to be largely humanitarian, the German debate around the issue has undergone a major paradigm shift and is now also being held in the light of Germany's future workforce demands. In this context, the rulings around the country's lengthy asylum procedures have been criticized for condemning thousands of young and eager asylum seekers to idleness, whereas early access to education and training would foster integration in all segments of the labor market. Asylum seekers have to wait on average 5.3 months-and in thousands of cases well over a year-until they learn whether or not they have been granted protected status, which would allow them to move around freely and take up employment.
Technically, access to higher education is less restricted in Germany than in many other European countries. Already today, asylum seekers would not have to wait to enroll in one of the tuition-free study programs at German universities. As of August, none of country's i6 states (Länder) prevents its universities from admitting asylum seekers who have yet to receive protected status. Nevertheless, only a handful of newcomers can be found in lecture halls across the country. This is in part due to the residency requirements imposed during the asylum process. Throughout this months-long wait for a decision, asylum seekers are required to reside in the administrative district they have originally been assigned to (Wohnsitzauflage). Since not all districts are home to a university or a university with a certain specialization, asylum seekers are unable to enroll until they have been granted permission to move to another administrative district. And although there is legal precedence for this, the red tape involved has discouraged most prospective students from trying. Those few who are not yet deterred often end up unable to prove that they possess the needed qualifications to enroll in a study program. Generally, German universities require international applicants to provide a foreign school-leaving certificate or a foreign academic credential in order to be admitted. At least one of these credentials needs to be considered equivalent to its German counterpart. So even if an applicant has managed to bring his or her diplomas to Germany, the documents may not be considered sufficient by a university's admissions office.

\section{FINANCIAL BARRIERS}

In addition to legal obstacles, financial requirements pose another barrier for asylum seekers. Although studying at a German university is still free of charge (with the exception of a very modest biannual administrative fee of around EUR Ioo to 300), the newcomers are required to pay for learning materials and their own living expenses, which on average amount to around EUR 800 per month. However, asylum seekers are not allowed to work during their first I5 months or until they are granted protected status, which often takes more than a year. As a result, the vast majority has to make do with non-cash benefits and a monthly government sponsored allowance of EUR 2I2. And while there are government-backed stipends for students (BAföG), asylum seekers are not allowed to apply for this type of financial aid until their asylum case has been decided. Even recent government pledges to expedite asylum processing will not make much of a difference for the would-be students, since asylum seekers can only apply for BAföG once they have resided in Germany for at least I5 months (recently lowered from the original four years). Finally, this situation is further complicated by restrictive regulations around opening 
a bank account for asylum seekers, which can make it very difficult to receive stipend money, pay for rent or university fees.

\section{Emerging Solutions}

To help lower these and other access barriers, the federal government, state governments, universities, and civil society initiatives have come up with some concrete measures: In August, the German Federal Ministry of Education and Research pledged to reserve an additional 2,400 places at Germany's pathway colleges (Studienkollegs), which prepare prospective international students for university studies in Germany. In conjunction with this measure, some states like Lower Saxony and Saarland have agreed to drop formal admission requirements for applicants with sufficient German language skills, who successfully complete a Studienkolleg program. Meanwhile, the state of Baden-

\section{In August, the German Federal Minis- try of Education and Research pledged to reserve an additional 2,400 places at Germany's pathway colleges (Studien- kollegs), which prepare prospective in- ternational students for university stud- ies in Germany.}

Wuerttemberg is offering 50 scholarships of up to EUR 750 per month to Syrian students whose asylum case has been decided. In addition, dozens of universities such as the University of Hildesheim and the University of Bayreuth encourage asylum seekers to take German lessons or audit courses. Others go one step further: The Ludwig Maximilians University in Munich has started to admit asylum seekers as exchange students so that they can study for academic credit even without German-language skills. These efforts are underpinned by various grassroots initiatives such as Kiron, a tuition-free online university for asylum seekers, which offers accredited degrees in partnership with brick and mortar universities, such as the University of Rostock.

With the help of these and other initiatives and programs, asylum seekers are increasingly able to play a more active role in their educational and professional development. However, since integration is not a one-way street, universities will need to be prepared to help their new students adjust to student life on and off campus.

\section{The Scourge of Fraud and Corruption in Higher Education}

\section{GoOlam MOHAMEdBhal}

Goolam Mohamedbhai is former Vice-Chancellor, University of Mauritius, and former Secretary-General, Association of African Universities. E-mail: g_t_mobhai@yahoo.co.uk.

$\mathrm{N}$ o sector appears to be immune from fraud and corruption, not even those that have a direct impact on society's welfare: health, education, sports, politics, or religion. Higher education is no exception. "Corruption for resources, fame and notoriety places extraordinary pressures on higher education institutions (...). In some instances, corruption has invaded whole systems of higher education and threatens the reputation of research products and graduates, regardless of their guilt and innocence." This quote, which comes from Transparency International's 2013 Global Corruption Report: Education captures the situation. That corruption had infected higher education has been known for decades. What is perhaps not realized is its magnitude, its extent and that it is constantly growing. Hardly any week goes by now without the appearance of an article on corruption in higher education. The stories cover not only individual students or faculty but also whole institutions and even countries. Corruption in higher education has even crossed borders and become global. And what is surfacing is probably only the tip of the iceberg.

Corruption in higher education affects the developed and the developing world equally, even if the motivation and the actors are different. In simplistic terms, in the West, corruption arises more frequently from the commercialization of higher education, from the growing tendency to convert the university into a corporate, money-generating entity, and from the strong linkages between university and industry, the latter often funding and controlling the research of the former. In the developing world, corruption results more often from the pressure to obtain admission to prestigious universities, especially to professional programs, and to succeed once admitted. It also results from the compulsion among faculty to raise additional income and to quickly climb the academic ladder through publications and research.

\section{Global Scan}

A quick scan of recent stories on fraud and corruption in some countries around the world gives an insight into the seriousness of the situation. 